\title{
Short Communication: Prediction of body weight based on body measurements in female Saburai goat
}

\author{
AKHMAD DAKHLAN,", MUHAMMAD DIMA IQBAL HAMDANI, DELSI RUSITAIMI PUTRI, SULASTRI, \\ ARIF QISTHON \\ Department of Animal Husbandry, Faculty of Agriculture, Universitas Lampung. Jl. Prof. Soemantri Brojonegoro No. 1, Gedung Meneng, Bandar \\ Lampung 35145, Lampung, Indonesia. Tel.: +62-721-704946, Fax.: +62-721-770347, `email: akhmad.dakhlan@fp.unila.ac.id
}

Manuscript received: 17 January 2021. Revision accepted: 19 February 2021.

\begin{abstract}
Dakhlan A, Hamdani MDI, Putri DR, Sulastri, Qisthon A. 2021. Short Communication: Prediction of body weight based on body measurements in female Saburai goats. Biodiversitas 22: 1391-1396. Saburai goat is a new composite breed in Lampung Province with little information on its performance. This research aimed to predict body weight based on body measurements, namely body length (BL), chest girth (CG), and shoulder height (SH) in female Saburai goats. This study used 42 female Saburai goats aged 3-4 years. The method used in this study was a survey, namely all-female Saburai goats aged 3-4 years were used for this research. The data obtained were analyzed using correlation and simple and multiple linear regression analysis using R program. Coefficient determination $\left(\mathrm{R}^{2}\right)$, adjusted $\mathrm{R}^{2}$, residual standard error (RSE), Akaike information criterion (AIC), Bayesian information criterion (BIC), and stepwise regression analysis were used to find the best and most parsimonious regression model to predict BW based on body measurements. The results showed that BL, CG, and SH were positively and significantly correlated with BW of female Saburai goats with correlation coefficients of $0.858,0.956$ and 0.862 , respectively. Chest girth was the best predictor for BW if using single predictor with regression equation of $\hat{\mathrm{Y}}=-31.17+0.93 \mathrm{X}_{2}$. However, combination of $\mathrm{BL}$ and $\mathrm{CG}$ was the best and most parsimonious regression model in predicting BW of female Saburai goat with regression equation of $\hat{Y}=-36.09+0.31 X_{1}+0.72 X_{2}$ with $R^{2}=0.941$, adjusted $R^{2}=0.938$, $\mathrm{RSE}=2.842, \mathrm{AIC}=216.73$ and $\mathrm{BIC}=223.78$. In conclusion, all body measurements in this study (particularly combination of BL and CG) could be used as predictor for BW with high accuracy of prediction. The result of this study suggested that CG and BL could be as indirect criteria to improve BW of female Saburai goats.
\end{abstract}

Keywords: Body length, chest girth, correlation, regression, shoulder height

\section{INTRODUCTION}

Saburai goat is a new composite goat that results from grading-up between female Ettawa Grade (EG) goat and male Boer goat with a genetic composition of $25 \%$ EG goat and $75 \%$ Boer goat. The Saburai goat has been designated as a Lampung local goat by the Indonesian Ministry of Agriculture in 2015 (Kementan 2015).

In 2018, the Saburai goats population amounted to 3,293 individuals (Sulastri et al. 2019). The population growth is still low and need to be increased. To increase the productivity of the Saburai goats, the Lampung Provincial Government established a goat breeding center in Gedong Tataan Sub-district, Pesawaran District, while the implementation of developing of goat in the field was centered in Tanggamus District.

For breeders in Tanggamus District, Saburai goats are their livelihood, both goats are kept as a part-time job or as their main source of livelihood. The advantages of Saburai goats are that this goat can adapt to various environmental conditions, its reproductive potential is high, and the number of kids is more than one. In addition, the proportion of meat to bone of Saburai goat is greater than that of EG goat. To develop the future of Saburai goats required knowledge and information on the performance of
Saburai goats such as body weight and body measurements of the goat.

To find out the goat's body weight is by weighing the goat. However, the conditions in the field, especially in remote areas, the availability of scales is rather difficult. Therefore, we need another way to find out the weight of the goat, one of them is by investigating the correlation between the body measurements of the goat with its body weight. Biometric measurements are used to assess several characteristics of animals. These measurements provide important evidence for the growth of the breed and the properties that change with environmental effects and feeding factors. In addition, body measurements are important data sources in terms of reflecting the breed standards which are also important in giving information about the morphological structure and development ability (Cam et al. 2010a; Cam et al. 2010b). According to previous studies that body measurements such as body length, chest girth, and shoulder height are highly and positively correlated to body weight in cattle (Vanvanhossou et al. 2018; Paputungan et al. 2013; Haq et al. 2020; Sakar et al. 2020), in sheep (Feyissa et al. 2018; Sabbioni et al. 2020; Khan et al. 2014; Musa et al. 2015; Afolayan et al. 2006; Agamy et al. 2015; Cam et al. 2010b), and in goats (Adeyinka and Mohammed 2006; 
Khan et al. 2006; Abdallah et al. 2019; Abd-Allah et al. 2019; Dakhlan et al. 2020; Alex et al. 2010; Cam et al. 2010a; Chitra et al. 2012; Tsegaye et al. 2013). The high and positive relationship between body weight and body measurements can be utilized to form a formula of equation, namely regression equation. Therefore, goat body measurements can be used as predictors in the regression equation to estimate goat body weight. On the other hand, research on prediction of body weight of Saburai goat is very limited, therefore, the current study aimed to predict live body weight of female Saburai goat based on body measurements, namely body length (BL), chest girth (CG) and shoulder height $(\mathrm{SH})$. This research is expected to be very useful for predicting goat weights, especially in situations in the field with small-scale farmers with difficulties in getting the scales.

\section{MATERIALS AND METHODS}

This research was conducted in May-June 2019 at the goat breeding center, namely in the Regional Technical Implementation Unit of the Negerisakti Goat Breeding Center, Gedong Tataan Sub-district, Pesawaran District, Lampung Province. The goat used in this study were 42 female Saburai goats aged 3-4 years. The goats were reared intensively with feedstuff given were forages consisted of legume such as "Gamal" (Gliricidia sepium), Indigofera sp., and "Kaliandra" (Calliandra calothyrsus) and grass such as "Rumput setaria" (Setaria sphacelata) which were cut and carried from field. The tools used in this study were $250 \mathrm{~kg}$ capacity scales with sensitivity $0.1 \mathrm{~kg}, 150 \mathrm{~cm}$ capacity measuring tapes with sensitivity $0.1 \mathrm{~cm}$, and 150 $\mathrm{cm}$ capacity measuring sticks with sensitivity $0.1 \mathrm{~cm}$.

The method used was a survey method, which was observing all goats at the study site in accordance with predetermined goat criteria, which were 3-4 years old. Data on body weight (BW) and body measurements (body length $=\mathrm{BL}$, chest girth $=\mathrm{CG}$, and shoulder height $=\mathrm{SH}$ ) of the Saburai goat were analyzed for correlation and regression using the $\mathrm{R}$ program ( $\mathrm{R}$ Core Team 2020). Correlations between variables were analyzed using Pearson correlation, while regression between body weight and body measurements was analyzed using simple and multiple regression. Simple regression and multiple regression equations can be formulated using the regression equation.

$$
\begin{aligned}
& \hat{Y}=a+b_{1} X_{1} \\
& \hat{Y}=a+b_{2} X_{2} \\
& \hat{Y}=a+b_{3} X_{3} \\
& \hat{Y}=a+b_{1} X_{1}+b_{2} X_{2} \\
& \hat{Y}=a+b_{1} X_{1}+b_{3} X_{3} \\
& \hat{Y}=a+b_{2} X_{2}+b_{3} X_{3} \\
& \hat{Y}=a+b_{1} X_{1}+b_{2} X_{2}+b_{3} X_{3}
\end{aligned}
$$

Where: $\hat{\mathrm{Y}}$ is the dependent variable which is $\mathrm{BW}, \mathrm{X}$ is the independent variable, $\mathrm{a}$ is a constant, b1, b2, and b3 are the regression coefficients for the variable of $\mathrm{BL}\left(\mathrm{X}_{1}\right), \mathrm{CG}$ $\left(\mathrm{X}_{2}\right)$, and $\mathrm{SH}\left(\mathrm{X}_{3}\right)$. Bodyweight $(\mathrm{BW})$ was measured by weighing the goat using a $250 \mathrm{~kg}$ capacity scale (Gea brand), while CG was measured in a circular circumference around the chest cavity just behind the elbow of the forelegs using mater tape. Body length (BL) was measuring the distance between the shoulder joint and a lump of sitting bone using a measuring stick. Shoulder height was measured perpendicular from the highest shoulder over the feet to the ground using a measuring stick (Khan et al. 2006; Nurhayati et al. 2014; Abdallah et al. 2019).

Normality of data distribution was checked using boxplot and Kolmogorov-Smirnov and Shapiro test. To find the best and most parsimonious regression model for predicting goat body weight we used coefficient of determination $\left(\mathrm{R}^{2}\right)$, adjusted $\mathrm{R}^{2}$, residual square error (RSE), Akaike information criterion (AIC) and Bayesian information criterion (BIC) and also stepwise regression analysis (Dakhlan et al. 2020). The model with the highest $\mathrm{R}^{2}$ and adjusted $\mathrm{R}^{2}$ and the lowest RSE, AIC and BIC values was the best regression model to predict the bodyweight of female Saburai goats. We also checked multicollinearity for independent variables in multiple linear regression (Dakhlan 2019).

\section{RESULTS AND DISCUSSION}

\section{Body measurements}

This research on average body weight and body measurements including $\mathrm{BL}, \mathrm{CG}$, and $\mathrm{SH}$ are presented in Table 1 and Figure 1. These table and figure indicated that the means and medians of body weights and body measurements of female Saburai goats were similar meaning that the data were balance between below and upper the median. Based on Kolmogorov-Smirnov and Shapiro test indicated that the body weight and body measurements data of female Saburai goats were normally distributed.

\section{Correlation and regression between body measurements and bodyweight of female Saburai goat}

The correlation analysis of BW of Saburai goat with body measurements is presented in Table 2 and described in Figure 2. Based on the analysis of the correlation coefficient value of body measurements on $\mathrm{BW}$ of the Saburai goat, CG has the highest correlation value (r) of 0.956 followed by $\mathrm{SH}$ of 0.862 and the lowest BL, namely 0.858. Furthermore, the correlation between $\mathrm{BL}$ and $\mathrm{SH}$ was the highest $(0.921)$ while correlation between $\mathrm{BL}$ and CG was the lowest among the body measurements.

Correlation between BW and body measurements (either single or combination of body measurements) and regression equation along with selection parameters for body weight prediction of Saburai goat based on body measurements are presented in Table 3. 
Table 1. Statistics of body weight and body measurements of female Saburai goats aged 3-4 years

\begin{tabular}{lccccccc}
\hline Variables & n & Mean & Sd & Median & Minimum & Maximum & CV\% \\
\hline Bodyweight $(\mathrm{kg})$ & 42 & 32.10 & 11.43 & 32.70 & 14.60 & 52.50 & 35.61 \\
Body length $(\mathrm{cm})$ & 42 & 61.16 & 10.25 & 63.00 & 43.00 & 79.00 & 16.13 \\
Chest girth $(\mathrm{cm})$ & 42 & 68.02 & 13.16 & 67.00 & 50.00 & 86.00 & 17.28 \\
Shoulder height $(\mathrm{cm})$ & 42 & 58.79 & 7.04 & 60.00 & 45.00 & 70.00 & 11.97 \\
\hline
\end{tabular}
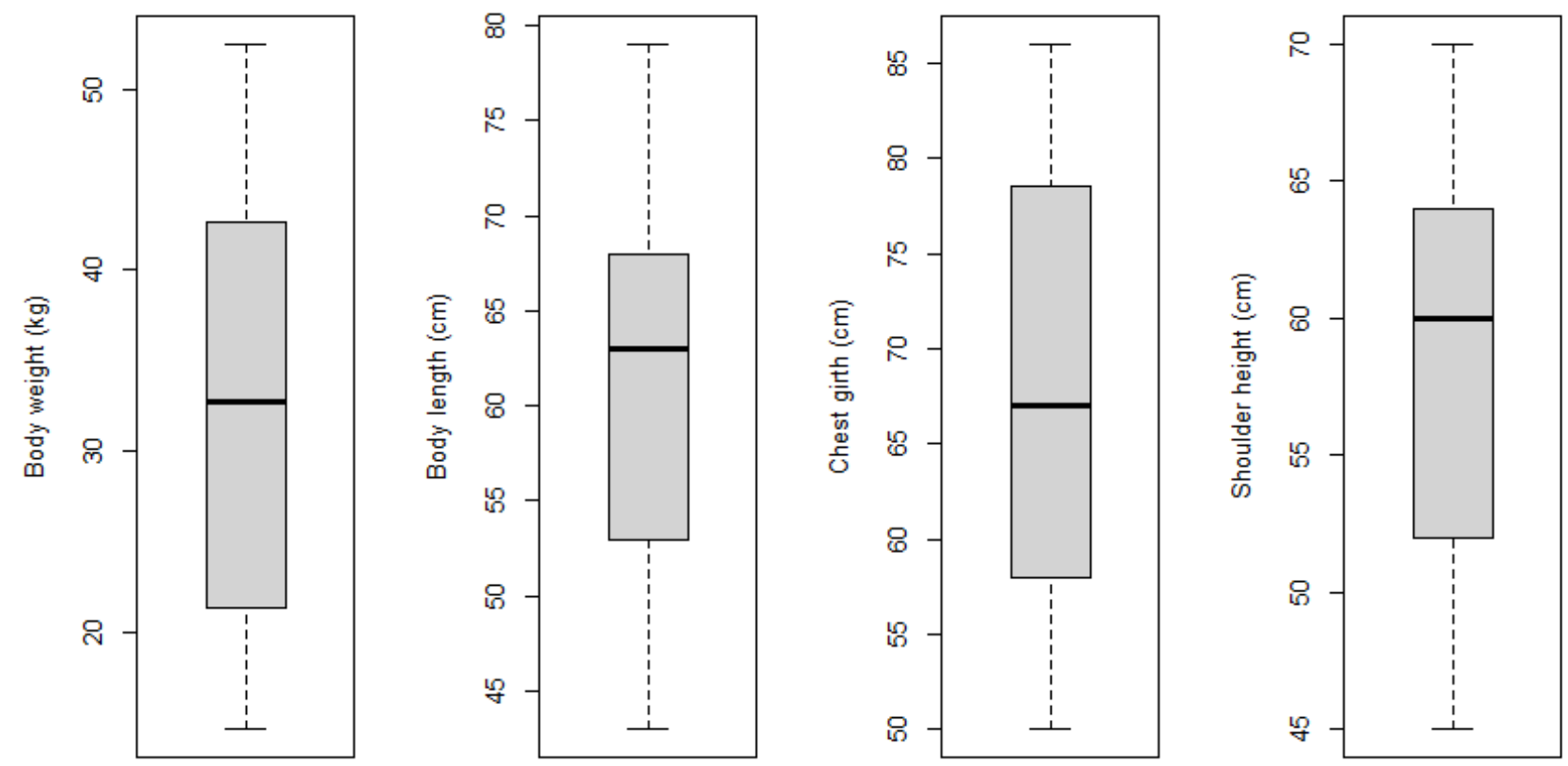

Figure 1. Boxplot of body weight and body measurements of female Saburai goats aged 3-4 years
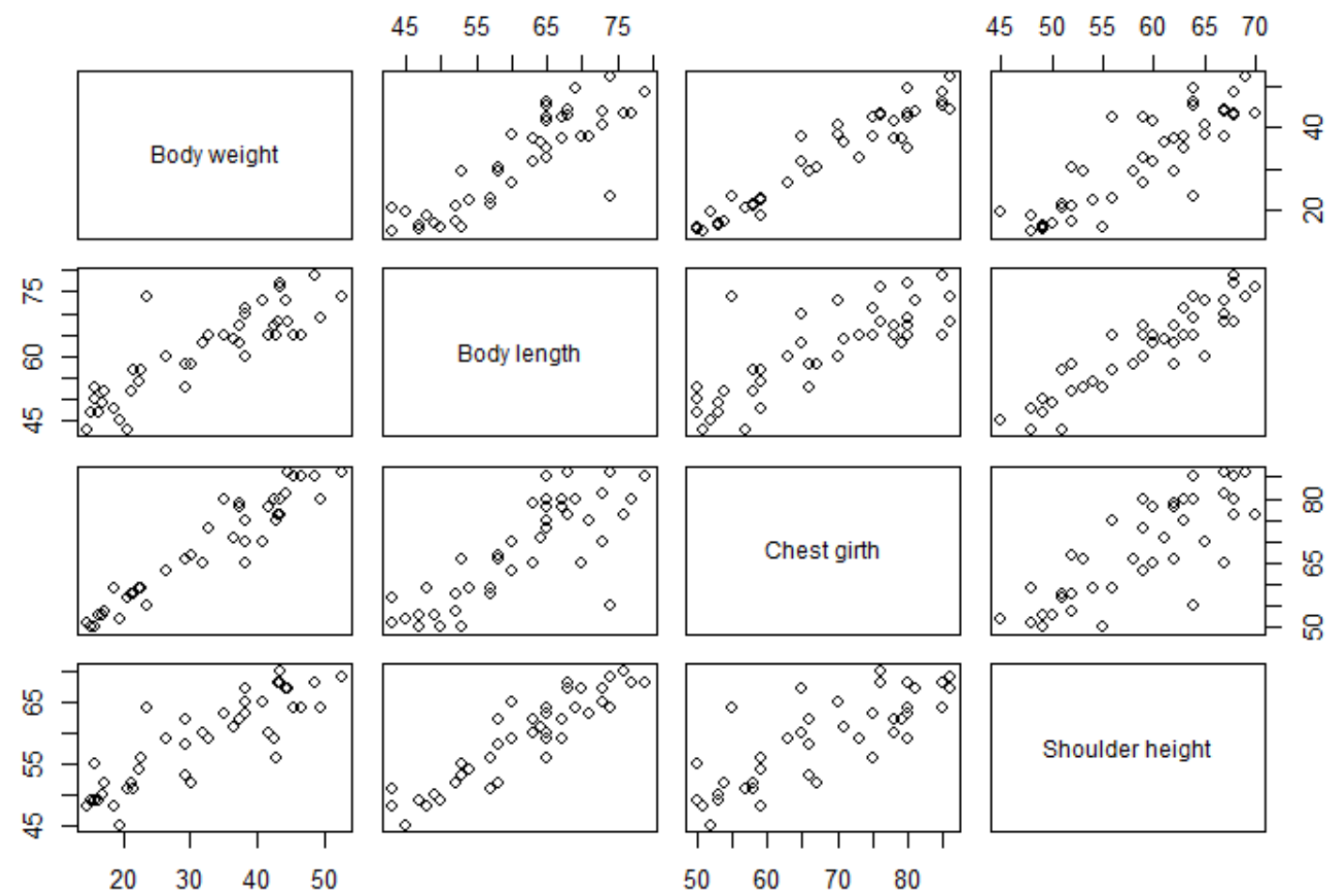

$\begin{array}{llll}50 & 60 & 70 & 80\end{array}$

Figure 2. Correlation plot among variables 
Table 2. Correlations among variables

\begin{tabular}{lcccc}
\hline & Bodyweight & Body length & Chest girth & Shoulder height \\
\hline Bodyweight & 1 & & & \\
Body length & 0.858 & 1 & 1 & \\
Chest girth & 0.956 & 0.793 & 0.804 & 1 \\
Shoulder height & 0.862 & 0.921 & \\
\hline
\end{tabular}

Table 3. Regression equation for prediction of body weight of Saburai goat based on body measurements along with their parameters

\begin{tabular}{lcccrrr}
\hline \multicolumn{1}{c}{ Regression equation } & $\mathbf{r}$ & $\mathbf{R}^{\mathbf{2}}$ & Adj. $\mathbf{R}^{\mathbf{2}}$ & $\mathbf{R S E}$ & AIC & BIC \\
\hline$\hat{\mathrm{Y}}=-28.69+0.99 \mathrm{X}_{1}$ & $0.858^{* *}$ & 0.736 & 0.729 & 5.946 & 279.30 & 284.58 \\
$\hat{\mathrm{Y}}=-31.17+0.93 \mathrm{X}_{2}$ & $0.956^{* *}$ & 0.915 & 0.913 & 3.381 & 230.74 & 236.02 \\
$\hat{\mathrm{Y}}=-50.24+1.40 \mathrm{X}_{3}$ & $0.862^{* *}$ & 0.744 & 0.737 & 5.855 & 277.97 & 283.25 \\
$\hat{\mathrm{Y}}=-36.09+0.31 \mathrm{X}_{1}+0.72 \mathrm{X}_{2}$ & $0.962^{* *}$ & 0.941 & 0.938 & 2.842 & 216.73 & 223.78 \\
$\hat{\mathrm{Y}}=-43.10+0.48 \mathrm{X}_{1}+0.78 \mathrm{X}_{3}$ & $0.877^{* *}$ & 0.770 & 0.759 & 5.614 & 275.29 & 282.34 \\
$\hat{\mathrm{Y}}=-42.33+0.72 \mathrm{X}_{2}+0.43 \mathrm{X}_{3}$ & $0.967^{* *}$ & 0.939 & 0.936 & 2.888 & 218.14 & 225.18 \\
$\hat{\mathrm{Y}}=-39.68+0.20 \mathrm{X}_{1}+0.70 \mathrm{X}_{2}+0.21 \mathrm{X}_{3}$ & $0.954^{* *}$ & 0.943 & 0.939 & 2.823 & 217.09 & 225.90 \\
\hline
\end{tabular}

Note: $\hat{Y}$ : Body weight, $\mathrm{X}_{1}$ : Body length, $\mathrm{X}_{2}$ : Chest girth, $\mathrm{X}_{3}$ : Shoulder height. ${ }^{*}$ Significant at $(\mathrm{P}<0.01)$

The highest correlation coefficient between BW and combination body measurements was between BW and combination of CG and SH (0.967), while the lowest correlation coefficient between $\mathrm{BW}$ and combination of body measurements was between $\mathrm{BW}$ and combination of $\mathrm{BL}$ and SH (0.877). Multicollinearity test for regression equation of $\mathrm{BW}$ on combination of $\mathrm{BL}$ and $\mathrm{CG}$ and $\mathrm{BW}$ on combination of $\mathrm{CG}$ and $\mathrm{SH}$ resulted in multicollinearity value under 5 indicating no multicollinearity among the body measurements. On the contrary, multicollinearity test for regression equation of $\mathrm{BW}$ on $\mathrm{BL}$ and $\mathrm{SH}$ and also $\mathrm{BW}$ on $\mathrm{BL}, \mathrm{CG}$ and $\mathrm{SH}$ resulted in multicollinearity value above 5 indicating there was multicollinearity among the body measurements. The existence of multicollinearity of regression equation implies that the information provided by one body measurement about the $\mathrm{BW}$ is redundant in the presence of the other body measurements.

\section{Discussion}

Figure 1 shows us that BW and body measurements data were normally distributed. The results showed that bodyweight of the female Saburai goat was $32.10 \mathrm{~kg}$ on average with a standard deviation of $11.43 \mathrm{~kg}$, median $32.70 \mathrm{~kg}$, smallest data (minimum) $14.6 \mathrm{~kg}$, largest data (maximum) $52.5 \mathrm{~kg}$ and variation coefficient of $35.61 \%$. Likewise, the body measurements of the Saburai goat can be seen in Table 1. This result indicated that goats body weight variation was high enough although their ages were close to each other (3-4 years old). This variation might be caused by the difference of their genetic potential for growth, because their environmental factor such as feeding and rearing management was relatively the same. Consequently, this big body weight variation could be a good indicator for a successful selection program.

The results of this study showed lower results compared to the results reported by Dakhlan et al. (2020) that the BW, BL, CG and SH of adult female Ettawa Grade (EG) goats were $37.07 \mathrm{~kg}, 71.27 \mathrm{~cm}, 78.33 \mathrm{~cm}$ and $73.86 \mathrm{~cm}$, respectively. Body measurements of female Saburai goat of current study was lower than that of female Jawarandu goats of which the mean body length, chest girth and shoulder height were $70.63 \pm 5.99 \mathrm{~cm}, 75.86 \pm 6.02 \mathrm{~cm}$, and $67.99 \pm 5.87 \mathrm{~cm}$, respectively (Nurhayati et al. 2014). This difference may be caused by the differences in goat breeds and the environment and also the feed management applied. Bodyweight and body measurements of goats are greatly affected by environmental factors which produce varied body sizes, even in the same breed (Devendra and Burns 1994).

Table 3 shows that all the seven regression equations could predict $\mathrm{BW}$ of Saburai goat with significant correlation between body measurements and BW of Saburai goat. The result of this study indicated that CG was the best predictor for BW of female Saburai goat compared to using $\mathrm{BL}$ or $\mathrm{SH}$ if using only one body measurement. Addition of body measurement in the regression equation will increase the value of $\mathrm{R}^{2}$. However, combination of $\mathrm{BL}$ and $\mathrm{CG}$ (equation 4) was the best and more parsimonious predictor for BW of female Saburai goat with regression equation $\hat{\mathrm{Y}}=-36.09+0.31 \mathrm{X}_{1}+0.72 \mathrm{X}_{2}$. This is because of the high of $\mathrm{r}(0.962), \mathrm{R}^{2}(0.941)$ and adjusted $\mathrm{R}^{2}(0.938)$ and also the lowest AIC (216.73) and BIC (223.78) of the equation. In addition, there was no multicollinearity between BL and CG in equation 4. Although the highest $r$ was equation $6(0.967)$, but the other parameters were worse than equation 4. Likewise, equation 7 used all body measurements with the highest $\mathrm{R}^{2}$, adjusted $\mathrm{R}^{2}$ and the lowest RSE, but for $r$ and AIC and BIC, equation 4 was better and more parsimonious than equation 7 . In addition, there was multicollinearity among independent variables in this equation 7 indicated by the VIF (variance inflation factor) which were higher than 5 (6.98 for BL, 2.99 for CG, and 7.33 for $\mathrm{SH}$ ).

The best equation for equation 4 was supported by stepwise regression analysis which resulted in equation 4 where combination of $\mathrm{BL}$ and $\mathrm{CG}$ was the best predictor 
and parsimonious for predicting the weight of female Saburai goat. The result of current study is in accordance with the result reported by Adeyinka and Mohammed (2006) that combination of CG and BL was the best predictor for live body weight of female Nigerian Red Sokoto goats. The present study also agree with the results reported by Dakhlan et al. (2020) that combination of CG an BL was the best predictor and more parsimonious regression model for predicting BW of female Ettawa Grade goats. Furthermore, regression equation using combination of $\mathrm{BL}$ and $\mathrm{CG}$ resulted in the lowest MSE (mean square error, 8.181) although its $\mathrm{R}^{2}$ (0.719) was lower than that using combination of BL, CG and height at withers with $\mathrm{R}^{2}$ of 0.721 and MSE of 8.297 (Chitra et al. 2012). Three dimension (3D) figure describing regression model between BW and combination BL and CG can be seen in Figure 3.

Scatter plot and regression line if using single body measurements for predicting BW of female Saburai goat is shown in Figure 4. This figure shows us that bodyweight prediction using different single body measurements resulted in different accuracy indicated by the value of $\mathrm{R}^{2}$ (0.736, 0.915 and 0.744 if using BL, CG and $\mathrm{SH}$, respectively, as predictor) with different slope $(0.99,0.93$ and 1.40, respectively). In addition, if using BL and CG as predictor, the two regression lines were almost parallel with similar slope (0.99 and 0.93 , respectively), while regression line if using $\mathrm{SH}$ as predictor resulted in not parallel to each other indicated by the higher slope (1.40). The result of this study suggested that we cannot substitute body measurement one another to predict body weight of female Saburai goat if using single body measurement.

In conclusion, chest girth could be used as predictor of body weight of female Saburai goats if using single body measurement. Regression equation using combination of body length and chest girth resulted in the best prediction of body weight of female Saburai goat with more parsimonious.

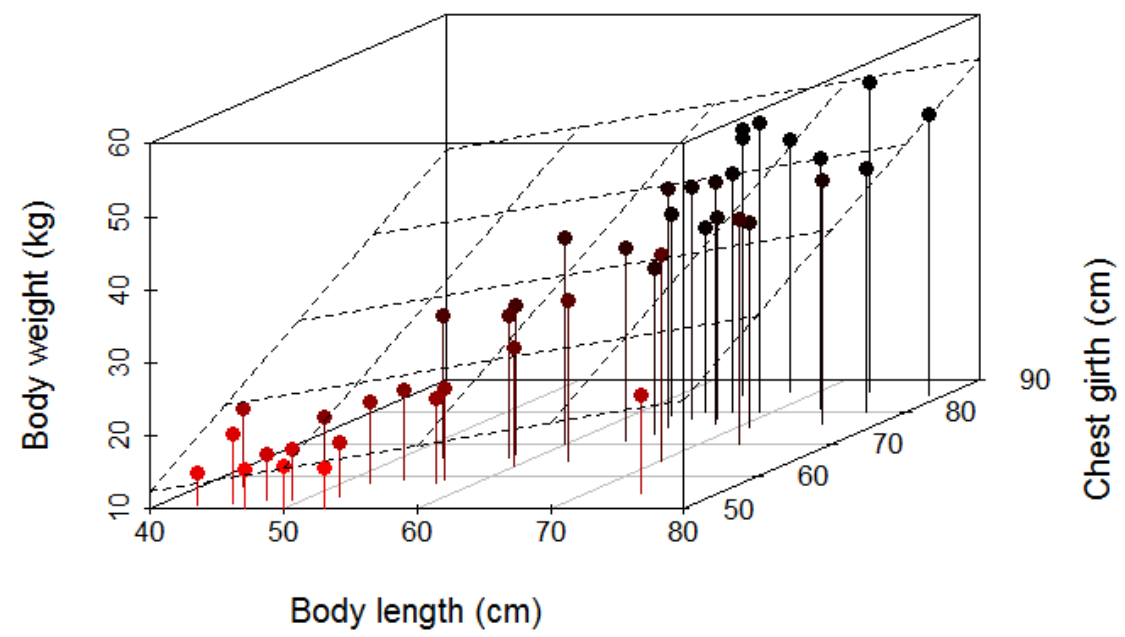

Figure 3. 3D visualisation for the best and parsimonious regression equation between BW and combination of BL and CG

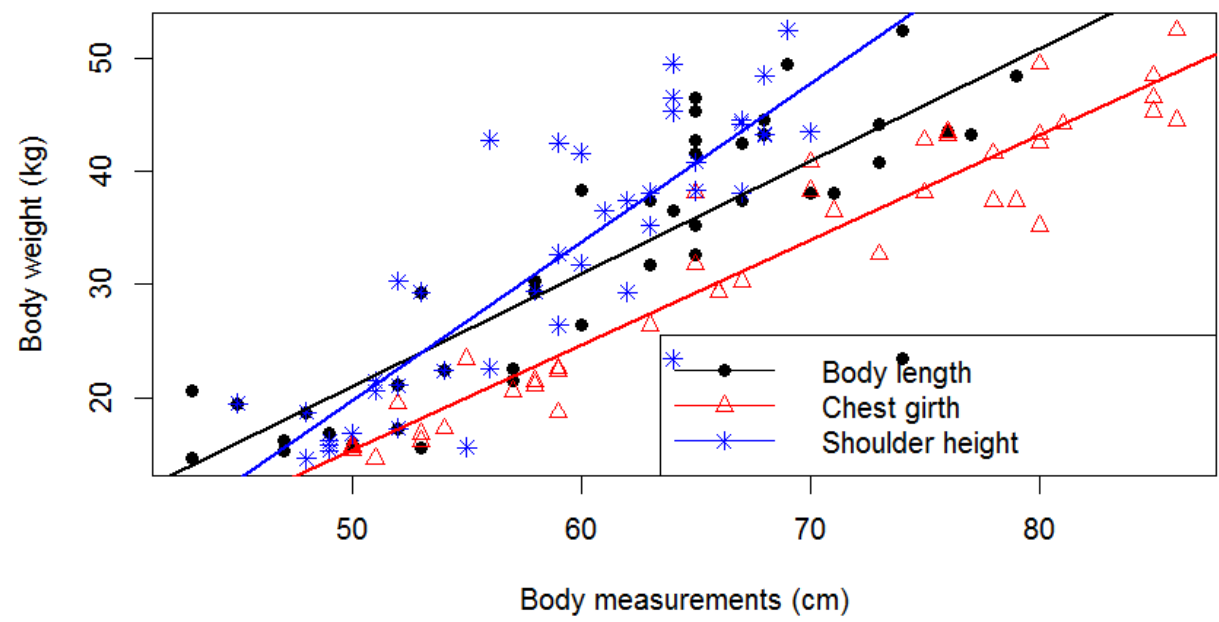

Figure 4. Scatter plot and regression line between body measurements and bodyweight of female Saburai goat 


\section{ACKNOWLEDGEMENTS}

This research was funded by a Faculty of AgricultureUniversity of Lampung Grant. Authors thank to all staff in the Regional Technical Implementation Unit of the Negerisakti Goat Breeding Center, Gedong Tataan Subdistrict, Pesawaran District, Lampung Province, Indonesia who facilitated this study.

\section{REFERENCES}

Abd-Allah S, Abd-El Rahman HH, Shoukry MM, Mohamed MI, Salman FM, Abedo AA. 2019. Some body measurements as a management tool for Shami goats raised in subtropical areas in Egypt. Bull Natl Res Cent 43 (1): 0-5. DOI: 10.1186/s42269-019-0042-9.

Abdallah S, Salman FM, Shoukry MM, El-Rahman HH, Mohamed MI, Abedo AA. 2019. Study of some morphological characteristics of Boer goat raised in Egypt. Adv Anim Vet Sci 7 (10): 888-897. DOI: 10.1177/1455072596013005-611.

Adeyinka IA, Mohammed ID. 2006. Accuracy of body weight prediction in Nigerian Red Sokoto goats raised in North-Eastern Nigeria using linear body measurement. Pak J Biol Sci 9 (15): 2828-2839. DOI: 10.3923/pjbs.2006.2828.2830.

Afolayan RA, Adeyinka IA, Lakpini CAM. 2006. The estimation of live weight from body measurements in Yankasa sheep. Czech J Anim Sci 51 (8): 343-348. DOI: 10.17221/3948-CJAS.

Agamy R, Abdel-Moneim AY, Abd-Alla MS, Abdel-Mageed II, Ashmawi GM. 2015. Using linear body measurements to predict body weight and carcass characteristics of three Egyptian fat-tailed sheep breeds. Asian J Anim Vet Adv 10 (7): 335-344. DOI: 10.3923/ajava.2015.335.344.

Alex R, Raghavan KC, Mercey KA. 2010. Prediction of body weight of Malabari goats from body measurements under field conditions. J Vet Anim Sci 41: 21-27.

Cam MA, Olfaz M, Soydan E. 2010a. Possibilities of using morphometrics characteristics as a tool for bodyweight prediction in Turkish Hair Goats (Kilkeci). Asian J Anim Vet Adv 5 (1): 52-59. DOI: 10.3923/ajava.2010.52.59.

Cam MA, Olfaz M, Soydan E. 2010b. Body measurements reflect body weights and carcass yields in Karayaka Sheep. Asian J Anim and Vet Adv 5 (2): 120-127. DOI: 10.3923/ajava.2010.120.127.

Chitra R, Rajendran S, Prasanna D, Kirubakaran A. 2012. Prediction of body weight using appropriate regression model in adult female Malabari goat. Vet World 5 (7): 409-411. DOI: 10.5455/vetworld.2012.409-411.

Dakhlan A. 2019. Experimental Design and Data Analysis Using R. Graha Ilmu (Matematika), Yogyakarta. [Indonesian]

Dakhlan A, Saputra A, Hamdani MDI, Sulastri. 2020. Regression models and correlation analysis for predicting body weight of female Ettawa Grade goat using its body measurements. Adv Anim Vet Sci 8 (11): 1142-1146. DOI: 10.17582/journal.aavs/2020/8.11.1142.1146.
Devendra C, Burns M. 1994. Goat Production in the Tropics. Translation. ITB Publisher, Bandung.

Feyissa AA, Kefeni KK, Amaha N. 2018. Application of body measurements of blackhead somali sheep as parameters for estimation of live weight. Iran J Appl Anim Sci 8 (4): 647-652.

Haq MS, Budisatria IGS, Panjono P, Maharani D. 2020. Prediction of live body weight using body measurements for Jawa Brebes (Jabres) cattle. J Anim Plant Sci 30 (3): 552-559. DOI: 10.36899/JAPS.2020.3.0065.

Kementan 2015. Kambing saburai. Surat Keputusan Nomor 359/Kpts/PK.040/6/2015. Tentang Penetapan Rumpun Kambing Saburai. [Indonesian]

Khan H, Muhammad F, Ahmad R, Nawaz G, Rahimullah, Zubair M. 2006. Relationship of body weight with linear body measurements in goats. J Agric Biol Sci 1 (3): 51-54.

Khan MA, Tariq MM, Eyduran E, Tatliyer A, Rafeeq M, Abbas F, Javed K. 2014. Estimating body weight from several body measurements in Harnai sheep without multicollinearity problem. J Anim Plant Sci 24 (1): 120-126.

Musa AM, Idam NZ, Elamin KM. 2012. Regression analysis of linear body measurements on live weight in Sudanese Shugor sheep. Online J Anim Feed Res. 2 (1): 27-29.

Nurhayati R, Dilaga W, Lestari CM. 2014. Hubungan antara ukuranukuran tubuh dengan bobot badan kambing Jawarandu betina pada kelompok umur muda dan dewasa di Kabupaten Blora Jawa Tengah. J Anim Agric 3 (4): 575-580. [Indonesian]

Paputungan U, Hakim L, Ciptadi G, Lapian HFN. 2013. The estimation accuracy of live weight from metric body measurements in Ongole grade cows. J Indones Trop Anim Agric 38 (3): 149-155. DOI: 10.14710/jitaa.38.3.149-155.

R CoreTeam 2020. R: A language and environment for statistical computing. R Foundation for Statistical Computing, Vienna, Austria. https://www.R-project.org/.

Sabbioni A, Beretti V, Superchi P, Ablondi M. 2020. Bodyweight estimation from body measures in Cornigliese sheep breed. Ital $\mathrm{J}$ Anim Sci 19 (1): 25-30. DOI: 10.1080/1828051X.2019.1689189.

Sakar CM, Unal I, Okuroglu A, Coskun MI, Zulkadir U. 2020. Prediction of live weight from chest girth from birth to 12 months of age in Yerli Kara cattle. Black Sea J Agric 3 (3): 200-204.

Sulastri, Adhianto K, Dakhlan A, Hamdani MDI, Siswanto S. 2019. Population performance of Saburai goat at Saburai Goat Breeding Area, Tanggamus District, Lampung Province. In IOP Conference Series: Earth and Environmental Science (Vol. 372, pp. 1-7). Purwokerto: IOP Publishing Ltd. DOI: 10.1088/17551315/372/1/012022.

Tsegaye D, Belay B, Haile A. 2013. Linear body measurements as predictor of body weight in Hararghe highland goats under farmers environment: Ethiopia. Glob Vet 11 (5): 649-656. DOI: 10.5829/idosi.gv.2013.11.5.76135.

Vanvanhossou SFU, Diogo RVC, Dossa LH. 2018. Estimation of live body weight from linear body measurements and body condition score in the West African Savannah Shorthorn cattle in North-West Benin. Cogent Food Agric 4 (1): 1-12. DOI: 10.1080/23311932.2018.1549767. 